\title{
Forecasts of the Payment Card Market in China
}

\author{
Wiśniewski Jerzy Witold \\ Department of Econometrics \& Statistics, Nicolaus Copernicus University, Poland \\ Received January 6, 2020; Revised February 20, 2020; Accepted March 12, 2020
}

Copyright $\mathrm{C} 2020$ by authors, all rights reserved. Authors agree that this article remains permanently open access under the terms of the Creative Commons Attribution License 4.0 International License

\begin{abstract}
The dynamic growth of the payment card market and the increase in the number of non-cash transactions is a global trend in payments. In most developed countries of the world, cashless payments have been displacing cash. One non-cash-payment instrument are payment cards, the use of which requires development of an infrastructure that allows cashless payments. The most important components of such infrastructure are ATMs and the points of sale (POS) enabling payment card transactions. The aim of the study is to assess the impact of the rising pay in China on various characteristics of the payment card market as well as to estimate forecasts of these significant variables representing the Chinese payment card market. A hypothesis is formulated that the increase in the citizens' wealth, expressed by the dynamically rising pay, has impact on the significant development of the payment card market in China. The tool used to analyze the mechanisms of the payment card market infrastructure will be an adequate econometric model consisting of many stochastic equations. The equation will be of a recursive-system nature. Consequently, forecasting from this model will be done using a chain technique. The rising pay in China stimulates the dynamic development of the payment card market. The number of these cards and their use for cashless transactions have been increasing in particular. Cashless card payments in China are currently at a relatively low level. To increase the intensity of such payments, new institutional solutions are required, especially of an economic nature, encouraging the payment card holders to carry out non-cash transactions.
\end{abstract}

Keywords Payment Card Market, China, Econometric Model, Stochastic Equations, Recursive-System

\section{Introduction}

The dynamic growth of the payment card market and the increase in the number of non-cash transactions is a global trend in payments. In most developed countries of the world, cashless payments have been displacing cash. One non-cash-payment instrument are payment cards, the use of which requires development of an infrastructure that allows cashless payments. The most important components of such infrastructure are ATMs and the points of sale (POS) enabling payment card transactions.

Payment card market research did not appear in economic literature until the end of the $20^{\text {th }}$ century. Humphrey, D. B., Pulley, L. B., \& Vesala, J. M. (1996), Hancock, D., Humphrey, D. B., \& Wilcox, J. (1999) and many others were pioneers in this area. Advanced results of these studies appeared at the beginning of the $21^{\text {st }}$ century. The following works are examples of such studies: Hauswald, R., \& Marquez, R. (2003), Amromin G., Chakravorti S. (2007), Rysman M. (2007), Sokołowska E. (2015a), Sokołowska E., Wiśniewski J.W. (2015), Wiśniewski J. W., Sokołowska E., Wu Jinghua (2017), containing various results of empirical research on the payment card market. Payment cards belong to the class of innovative financial instruments, as discussed, for example, in the works of: Tufano, P. (2003), Sokołowska E. (2015b). The need for and the consequences of cash payment replacement by electronic money have been expressed, for instance, in an article written by a team of authors: Evans D. S., Webster K., Colgan G. K., Murray S. R. (2013). The impact the development of payment-card-market infrastructure has on the increase in the number of cards and transactions in Poland have been discussed in the work of Sokołowska E., Wiśniewski J.W. (2015). The article by Wiśniewski J.W. (2018) is devoted to the processes of cash payments being substituted by non-cash payments via payment cards.

The aim of the study is to assess the impact of the rising pay in China on various characteristics of the payment card market as well as to estimate forecasts of these significant variables representing the Chinese payment card market. A hypothesis is formulated that the increase in the citizens' wealth, expressed by the dynamically rising pay, has impact on the significant development of 
the payment card market in China.

The tool used to analyze the mechanisms of the payment card market infrastructure will be an adequate econometric model consisting of many stochastic equations. The equation will be of a recursive-system nature. Consequently, forecasting from this model will be done using a chain technique.

\section{Materials and Methods}

In the initial period of the payment card use by bank customers, cards were primarily used to withdraw cash from ATMs. This reduced the costs of the banking system as well as facilitated and accelerated the money owners' access to their cash. Along with the development of the infrastructure designed to support non-cash transactions using payment cards, dynamic increase in the number and the value of non-cash payments has been observed.

In modern countries, cash transactions have been declining. Cash is being replaced by electronic money. The subject of this study entails an analysis of the development of the infrastructure supporting payment cards in China as well as its impact on the number of payment cards and the transactions carried out. The ability to withdraw cash from ATMs and to make payments by the means of payment cards requires creation of a network of ATMs (ATM), followed by development of points of sale (POS) and construction of a merchant system (MERCHAND) in which payment card payments can be carried out. These networks have been developing differently in Europe and in China. The state of the population's equipment with payment cards is also different in these countries.

The empirical econometric equations presented in this paper will contain the following variables characterizing the payment card market and the pay in China:

$A P A Y$ - the average quarterly pays of the urban population in China (expressed in RMB),

$C A R D P P L$ - the number of payment cards per 1000 inhabitants in China,

$C A R D$ - the number of payment cards in China (in millions),

$P O S$ - the number of the points of sale realizing payments by payment cards (in millions)

MERCHAND - the number of merchants (in millions),

$M E R C D$ - the number of merchants per 1 million payment cards (in thousands),

$A T M$ - the number of ATMs (in millions),

VALTRCD - quarterly value of non-cash transactions via payment cards (expressed in RMB) per 1 payment card

Out of the above-mentioned variables, only the variable $C A R D$ will play the role of an exogenous variable in the model. Each of the other variables will be endogenous, described by an appropriate stochastic empirical equation.
As such, a system of seven recursive equations will be created ${ }^{1}$.

The study will incorporate the following form of linear econometric equations ${ }^{2}$ :

$$
y_{t}=\sum_{j=0}^{k} \alpha_{j} x_{t j}+\sum_{i=1}^{4} \beta_{i} y_{t-i}
$$

$$
+\sum_{l=1}^{4} \sum_{j=1}^{k} \lambda_{l j} x_{t-l, j}+\alpha_{k+1} t+\sum_{h=1}^{3} \gamma_{h} d q_{h}+\eta_{t},
$$

where:

$y_{t}$ - observations on the dependent variable $(\mathrm{t}=1, \ldots$, n),

$x_{t j}$ - observations on the exogenous variables,

$t$ - the time variable,

$d q 1, d q 2, d q 3$ - the dummy variables, taking the value of 1 in the distinguished quarter and 0 in the remaining quarters,

$\eta_{t}$ - the equation's random component,

$\alpha_{j}, \beta_{i}, \lambda_{l j}, \ldots, \gamma_{p}(\mathrm{j}=0,1, \ldots, \mathrm{k}, \mathrm{i}=1, \ldots, 4, \mathrm{l}=1, \ldots, 4, \mathrm{p}$ $=1,2,3)$ - the equation's structural parameters,

$\mathrm{n}=42$ - the number of statistical observations.

The study incorporates quarterly data, taken from the websites of The People's Bank of China (PBC) and the National Bureau of Statistics of China (NBSC), ranging from the first quarter of 2008 to the second quarter of 2018.

Using appropriate regression equations, the impact the pay $(A P A Y)$ has on the development of payment card infrastructure (ATM, POS, MERCHAND, MERCD) as well as the interaction between the infrastructure components will be examined. The impact the pay rise $(A P A Y)$ has on the number of payment cards per 1000 inhabitants $(C A R D P P L)$ and on the value of non-cash card transactions per 1 card quarterly (VALTRCD) will also be examined. Each empirical equation will include variable delays, an autoregression, a trend and quarterly seasonal fluctuations. Equation parameters were estimated using the OLS, via the GRETL package available on the Internet. The forecasts ${ }^{3}\left(\mathrm{y}_{T_{\mathrm{p}}}\right)$, with their average and relative forecast errors $\left(V_{T}, V_{T}^{*}\right)$ have been estimated using the GRETL package as well.

The results of the calculation showed that the model of the Chinese payment card market is recursive, whereas the

\footnotetext{
1 See: Wiśniewski J. W. (2016): Microeconometrics in Business Management, John Wiley \& Sons, Chichester, subchapter 2.1.

2 The research was based on the so-called the concept of compatible models, described inter alia in: Wiśniewski J.W., Zieliński Z.: Elementy ekonometrii (Elements of econometrics), Nicolaus Copernicus University, Toruń, 2004, Revised $5^{\text {th }}$ Edition, Chapter 5.

3 Adequate formulas for the predictor as well as the average and the relative prediction errors can be found in: Wiśniewski J. W. (2016): Microeconometrics in Business Management, John Wiley \& Sons, Chichester, pp. $24-25$.
} 
mechanism of the links between the endogenous variables can be illustrated by the following diagram:

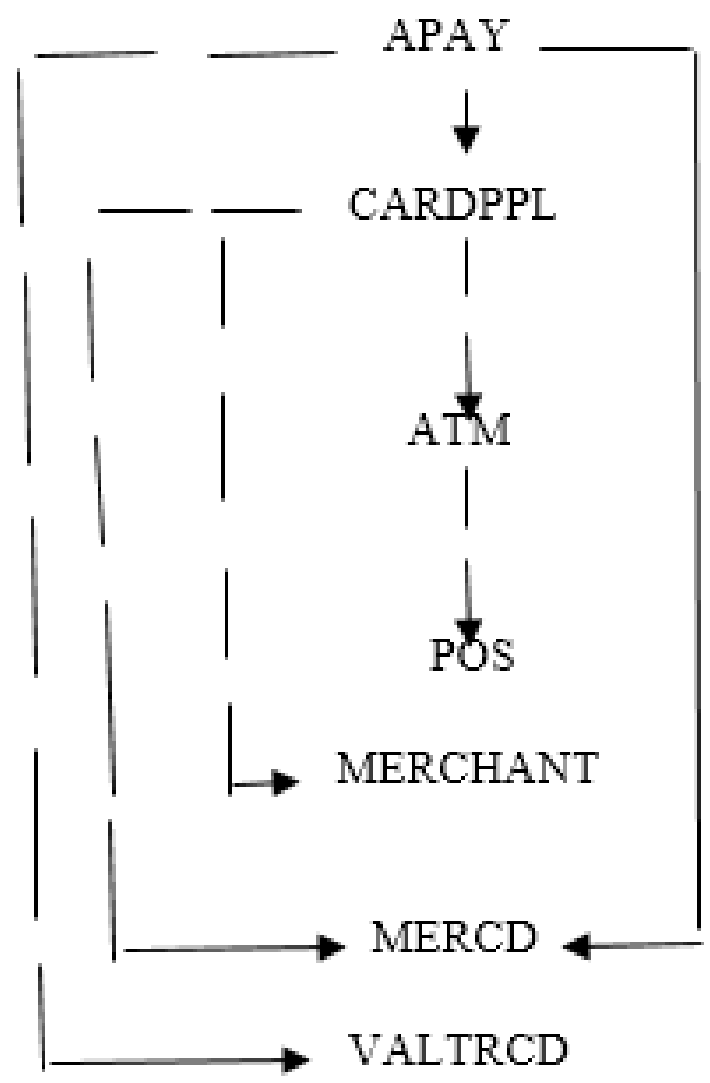

Diagram 1. The links in the model of the Chinese payment card market $^{4}$

\section{Empirical results}

To examine the impact the pay has on the characteristics of the payment card market, an equation describing the variable $A P A Y$ is required. The specificity of the pay is expressed by inertia and a positive trend. As such, autoregression of the variable $A P A Y$, its trend and seasonal fluctuations were examined. After statistically insignificant variables had been eliminated, the result presented in Table 1 was obtained.

The average pay of the urban population in China is characterized by a positive trend, signifying an average quarterly pay increase by RMB 58.95. What is more, a negative seasonal deviation appears in the second quarter, denoting a decline in the average pay by 184. 27 RMB. Similarly to many other cases - including China - first-, second-, third- and fourth-order autoregressions of the pay occur. A positive fourth-order autoregression, denoting continuation at the level of over $80 \%$, is specific of the Chinese reality. Moreover, the second- and the third-order autoregressions signify alternation of the fluctuations in the urban population's average pay, with a frequency of every second and every third quarter.

Having an empirical autoregressive equation with seasonal fluctuations, it is possible to automatically estimate short-term forecasts of the urban population's average pay $\left(A P A Y_{\mathrm{Tp}}\right)$ for subsequent quarters $(\mathrm{T}=1, \ldots$, $8)$. The forecasts obtained are presented in Table 2 and Figure 1. These forecasts are characterized by high precision. The relative prediction errors range from $0.78 \%$ in the first quarter of 2019 to $1.22 \%$ in the second quarter of 2020. It can be expected that these forecasts will have high degree of accuracy. The highest average pay should be expected in the first quarter of 2020 (around RMB 7417). What is more, a systematic increase in the urban population's average pay is expected. China has been systematically moving away from the cheap labor rule.

The first feature characterizing the payment card market in China is the number of cards per 1000 inhabitants $(C A R D P P L)$. The payment-card saturation of the Chinese community has been steadily and rapidly increasing. In the first quarter of 2008, there were almost 112 cards per 1000 inhabitants. In the second quarter of 2018, there were 517 cards per 1000 citizens of China. An almost fourfold increase in the population's equipment with cards (by $361.6 \%$ ) occurred. The value-variability mechanism of the variable CARDPPL is described by the empirical equation presented in Table 3. 
Table 1. Empirical equation of the urban population's average quarterly pay in China (APAY)

\begin{tabular}{|c|c|c|c|c|}
\hline Variable & Coefficient & t-statistic & Prob. p & Significance \\
\hline const & 1490.56 & 4.8044 & $<0.0001$ & $* * *$ \\
\hline time & 58.95 & 4.0145 & 0.0003 & $* * *$ \\
\hline $\mathrm{dq} 2$ & -184.269 & -3.9765 & 0.0004 & $* * *$ \\
\hline APAY_2 & -0.186657 & -3.8240 & 0.0006 & $* * *$ \\
\hline APAY_3 & -0.24477 & -4.0899 & 0.0003 & $* * *$ \\
\hline APAY_4 & 0.801248 & 12.2793 & $<0.0001$ & $* * *$ \\
\hline Mean dependent var. & 4205.011 & \multicolumn{2}{|c|}{ S.D. dependent var. } & 1076.750 \\
\hline Sum squared resid. & 92748.47 & \multicolumn{2}{|c|}{ S.E. of regression } & 53.83669 \\
\hline R-squared & 0.997838 & \multicolumn{2}{|c|}{ Adjusted R-squared } & 0.997500 \\
\hline $\mathrm{F}(5,32)$ & 2953.687 & \multicolumn{2}{|c|}{ Prob(F-statistic) } & $1.22 \mathrm{e}-41$ \\
\hline Log likelihood & -202.1208 & \multicolumn{2}{|c|}{ Akaike info criterion } & 416.2416 \\
\hline Schwarz criterion & 426.0671 & \multicolumn{2}{|c|}{ Hannan-Quinn criterion } & 419.7375 \\
\hline Autocorrel. coeff. (rho1) & 0.462952 & \multicolumn{2}{|c|}{ Durbin h-statistic } & 1.065139 \\
\hline
\end{tabular}

Source: Own calculations using the GRETL package

Table 2. Quarterly forecasts of the urban population's average pay in China $\left(A P A Y_{\mathrm{Tp}}\right)$ for the years $2018-2020$ (expressed in RMB)

\begin{tabular}{|c|c|c|c|c|}
\hline $\begin{array}{c}\text { Forecasted } \\
\text { period (T) }\end{array}$ & Forecast $\left(A P A Y_{\mathrm{T}_{\mathrm{p}}}\right)$ & $\begin{array}{c}\text { Average prediction } \\
\text { error }\left(\mathrm{V}_{\mathrm{T}}\right)\end{array}$ & Relative prediction error $\mathbf{V}_{\mathbf{T}}^{*}(\% \%)$ & $\begin{array}{c}\text { Forecast range at a confidence } \\
\text { level of } 95 \%\end{array}$ \\
\hline $2018: 3$ & 5780.53 & 53.84 & 0.93 & $(5670.87 ; 5890.19)$ \\
\hline $2018: 4$ & 5906.99 & 53.84 & 0.78 & $(5797.33 ; 6016.66)$ \\
\hline $2019: 1$ & 7018.17 & 54.77 & 0.96 & $(5766.99 ; 5996.61 ; 7129.73)$ \\
\hline $2019: 2$ & 5881.73 & 56.33 & 1.18 & $(5990.12 ; 6283.87)$ \\
\hline $2019: 3$ & 6137.00 & 72.11 & 1.16 & $(6090.20 ; 6384.63)$ \\
\hline $2019: 4$ & 6237.42 & 72.27 & 0.99 & $(7267.56 ; 7566.87)$ \\
\hline $2020: 1$ & 7417.22 & 73.47 & 1.22 & $(6143.58 ; 6456.61)$ \\
\hline $2020: 2$ & 6300.10 & 76.84 & \\
\hline
\end{tabular}

Source: Own calculations using the GRETL package 


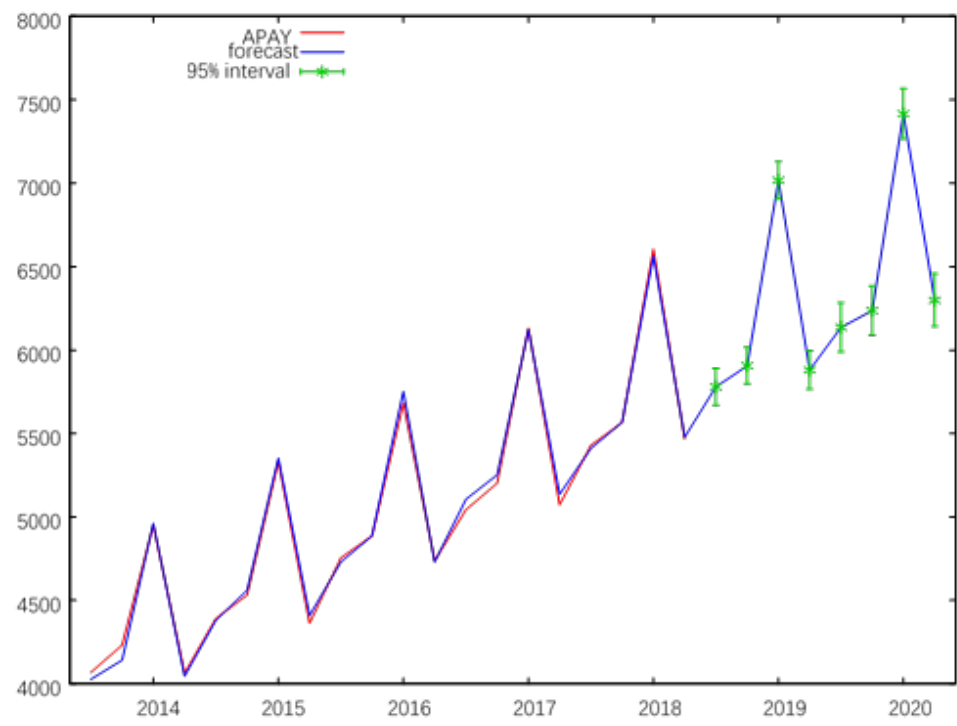

Source: Own calculations using the GRETL package

Figure 1. Quarterly forecasts of the urban population's average pay in China $\left(A P A Y_{\mathrm{T}}\right.$ ) for the years $2018-2020$ (expressed in RMB)

Table 3. Empirical equation of the number of payment cards in China (CARDPPL) per 1000 inhabitants

\begin{tabular}{|c|c|c|c|c|}
\hline Variable & Coefficient & t-statistic & Prob. $\mathrm{p}$ & Significance \\
\hline const & -26.0207 & -3.2459 & 0.0027 & $* * *$ \\
\hline APAY & 0.0113671 & 4.0362 & 0.0003 & $* * *$ \\
\hline APAY_3 & 0.00743985 & 3.0565 & 0.0044 & $* * *$ \\
\hline dq2 & 6.91545 & 2.7893 & 0.0087 & $* * *$ \\
\hline $\mathrm{dq} 3$ & 6.69261 & 3.5488 & 0.0012 & $* * *$ \\
\hline CARDPPL_1 & 0.851473 & 19.5222 & $<0.0001$ & $* * *$ \\
\hline Mean dependent var. & 303.7463 & \multicolumn{2}{|c|}{ S.D. dependent var. } & 117.9985 \\
\hline Sum squared resid. & 366.2464 & \multicolumn{2}{|c|}{ S.E. of regression } & 3.331422 \\
\hline R-squared & 0.999308 & \multicolumn{2}{|c|}{ Adjusted R-squared } & 0.999203 \\
\hline $\mathrm{F}(5,33)$ & 9528.105 & \multicolumn{2}{|c|}{ Prob(F-statistic) } & $4.11 \mathrm{e}-51$ \\
\hline Log likelihood & -99.01362 & \multicolumn{2}{|c|}{ Akaike info criterion } & 210.0272 \\
\hline Schwarz criterion & 220.0086 & \multicolumn{2}{|c|}{ Hannan-Quinn criterion } & 213.6085 \\
\hline Autocorrel. coeff. (rho1) & 0.216789 & \multicolumn{2}{|c|}{ Durbin h-statistic } & 1.407049 \\
\hline
\end{tabular}

Source: Own calculations using the GRETL package

Table 4. Forecasts of the number of payment cards per 1000 inhabitants in China $\left(C A R D P P L_{\mathrm{T}_{\mathrm{p}}}\right)$ for subsequent quarters of $2018-2020$

\begin{tabular}{|c|c|c|c|c|}
\hline $\begin{array}{c}\text { Forecasted period } \\
(\mathrm{T})\end{array}$ & $\begin{array}{c}\text { Forecast } \\
\left(C A R D P P L_{\mathrm{T}}\right)\end{array}$ & $\begin{array}{c}\text { Average prediction } \\
\text { error }\left(\mathrm{V}_{\mathrm{T}}\right)\end{array}$ & Relative prediction error $\mathbf{V}_{\mathbf{T}}^{*}(\% \%)$ & $\begin{array}{c}\text { Forecast range at a } \\
\text { confidence level of } 95 \%\end{array}$ \\
\hline $2018: 3$ & 528.0 & 3.33 & 0.63 & $(521.224 ; 534.780)$ \\
\hline $2018: 4$ & 539.8 & 4.38 & 0.76 & $(530.942 ; 548.746)$ \\
\hline $2019: 1$ & 554.1 & 5.00 & 0.90 & $(543.931 ; 564.267)$ \\
\hline $2019: 2$ & 562.6 & 5.40 & 0.96 & $(551.564 ; 573.554)$ \\
\hline $2019: 3$ & 573.4 & 5.68 & 0.99 & $(561.824 ; 584.941)$ \\
\hline $2019: 4$ & 585.3 & 5.87 & 1.00 & $(573.365 ; 597.264)$ \\
\hline $2020: 1$ & 600.4 & 6.01 & 1.00 & $(588.202 ; 612.653)$ \\
\hline $2020: 2$ & 609.4 & 6.11 & 1.00 & $(596.993 ; 621.836)$ \\
\hline
\end{tabular}




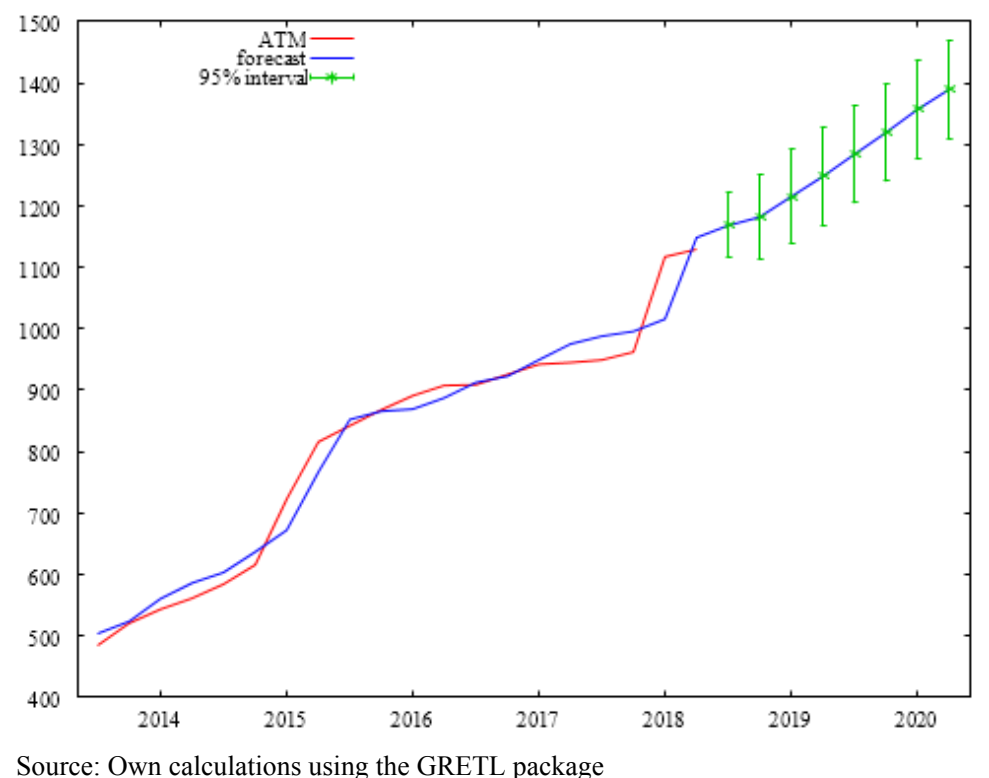

Figure 2. Forecasts of the number of payment cards per 1000 inhabitants in China $\left(C A R D P P L_{\mathrm{T}_{\mathrm{p}}}\right)$ for subsequent quarters of $2018-2020$

The simultaneous $(A P A Y)$ and the delayed by three quarters (APAY_3) average pay of the urban population in China stimulated the popularization of payment cards among the Chinese society. The first-order autoregression is strong, which signifies a continuation, in the next quarter, of over $85 \%$ of the number of cards from the previous period. Additionally, there are positive seasonal deviations in the second and the third quarter. The equation presented in Table 3 allows forecasting of the variable $C A R D P P L_{\mathrm{Tp}}$ using the earlier average pay forecasts $\left(A P A Y_{\mathrm{Tp}}\right)$. Forecasts of the number of payment cards per 1000 inhabitants are presented in table 4 and Figure 2.

The forecasts indicate that further dynamic increase in the number of payment cards q per 1000 inhabitants in China can be expected. The expected number will range from 528 payment cards per 1000 inhabitants in the third quarter of 2018 to over 604 cards in the second quarter of 2020. These forecasts are characterized by high accuracy, since their relative prediction errors do not exceed $1 \%$.

The next three empirical equations will describe the variables representing the payment card market infrastructure in China, i.e. ATM, POS, MERCHANT. They will allow estimation of short-term infrastructure development forecasts. It turns out that the number of ATMs $(A T M)$ and the number of the points of sale accepting non-cash payments via payment cards $(P O S)$ is not affected by the simultaneous pay (APAY).

In the empirical equation describing the variability mechanism of the number of ATMs, the delayed-by-four-quarters number of payment cards in China (CARD_4) is statistically significant, which increases the overall number of ATMs. Moreover, a positive first-order autoregression and a negative third-order autoregression occur in this equation. The equation description accuracy is high, since the $\mathrm{R}^{2}$ factor exceeds 0.99 . The high equation accuracy offers an opportunity to estimate precise $\left(A T M_{\mathrm{Tp}}\right)$ forecasts.

Table 6 and Figure 3 present forecasts of the number of ATMs in China for subsequent quarters, i.e. from the third quarter of 2018 to the second quarter of 2020. These forecasts are accurate sufficiently, since their relative prediction errors range from $2.22 \%$ in the third quarter of 2018 to $3.13 \%$ in the first and the second quarters of 2019. An increase in the number of ATMs in China can be expected, from 1168.3 million in the third quarter of 2018 to 1390.05 million in the second quarter of 2020. An increase in the number of ATMs is characteristic for countries where cash transactions predominate non-cash transactions. As such, progressive substitution with cashless payments that push cash out of trading should not be expected. 
Table 5. Empirical equation of the number of ATMs $(A T M)$ in China

\begin{tabular}{|c|c|c|c|c|}
\hline Variable & Coefficient & t-statistic & Prob. p & Significance \\
\hline const & -46.4795 & -2.0621 & 0.0467 & $* *$ \\
\hline CARDPPL_4 & 0.857855 & 2.8943 & 0.0065 & $* * *$ \\
\hline ATM_1 & 0.706535 & 6.4120 & $<0.0001$ & 300.3261 \\
\hline Mean dependent var. & 569.0658 & S.D. dependent var. & 26.68038 \\
\hline Sum squared resid. & 24914.50 & S.E. of regression & 0.992108 \\
\hline R-squared & 0.992534 & Adjusted R-squared & $6.01 \mathrm{e}-38$ \\
\hline F(2, 35) & 2326.587 & Prob(F-statistic) & 360.2929 \\
\hline Log likelihood & -177.1464 & Akaike info criterion & 362.0408 \\
\hline Schwarz criterion & 365.2056 & Hannan-Quinn criterion & 1.633482 \\
\hline Autocorrel. coeff. (rho1) & 0.194473 & Durbin h-statistic & \\
\hline
\end{tabular}

Source: Own calculations using the GRETL package

Table 6. Forecasts of the number of ATMs $\left(A T M_{\mathrm{Tp}}\right)$ in China for the following quarters of 2018-2020

\begin{tabular}{|c|c|c|c|c|}
\hline Forecasted period (T) & $\begin{array}{c}\text { Forecast } \\
\left(A T M_{\mathrm{T}}\right)\end{array}$ & $\begin{array}{c}\text { Average prediction } \\
\text { error }\left(\mathrm{V}_{\mathrm{T}}\right)\end{array}$ & Relative prediction error $\mathbf{V}_{\mathbf{T}}^{*}(\%)$ & $\begin{array}{c}\text { Forecast range at a confidence } \\
\text { level of } 95 \%\end{array}$ \\
\hline $2018: 3$ & 1168.30 & 25.93 & 2.22 & $(1115.60 ; 1221.00)$ \\
\hline $2018: 4$ & 1182.05 & 33.63 & 2.85 & $(1113.70 ; 1250.40)$ \\
\hline $2019: 1$ & 1215.31 & 38.00 & 3.13 & $(1138.09 ; 1292.54)$ \\
\hline $2019: 2$ & 1248.14 & 39.08 & 3.13 & $(1204.52 ; 1363.85)$ \\
\hline $2019: 3$ & 1284.19 & 39.20 & 3.05 & $(1239.97 ; 1399.39)$ \\
\hline $2019: 4$ & 1319.68 & 39.22 & 2.97 & $(1277.47 ; 1437.33)$ \\
\hline $2020: 1$ & 1357.40 & 39.33 & 2.90 & $(1309.87 ; 1470.22)$ \\
\hline $2020: 2$ & 1390.05 & 39.45 & 2.84 & \\
\hline
\end{tabular}

Source: Own calculations using the GRETL package

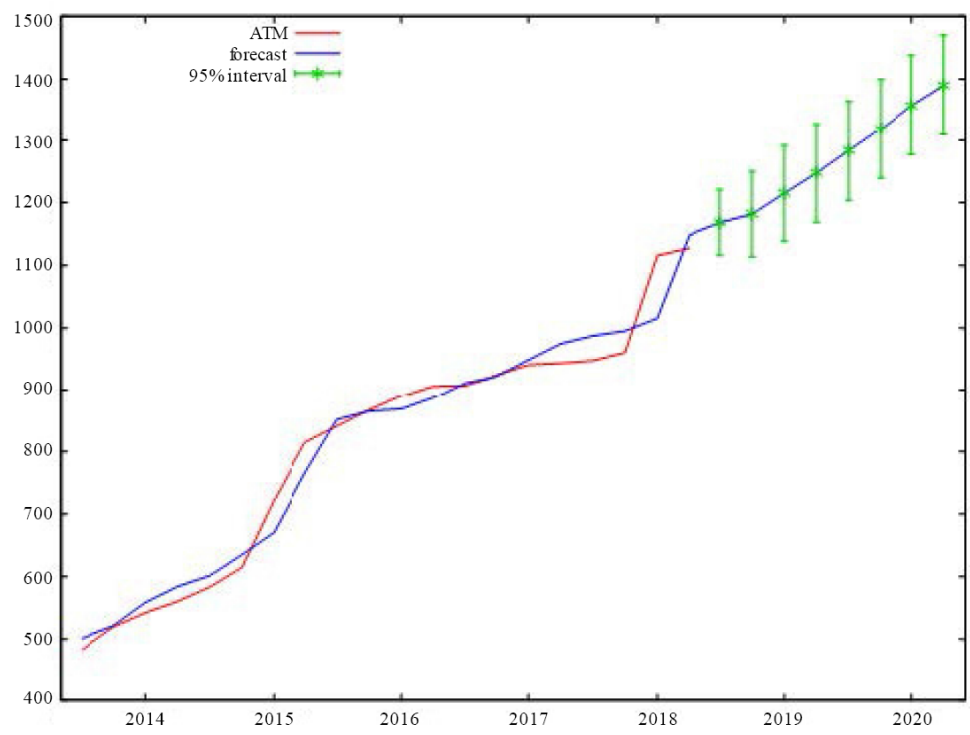

Source: Own calculations using the GRETL package

Figure 3. Forecasts of the number of ATMs $\left(A T M_{\mathrm{T}}\right)$ in China for the following quarters of 2018-2020 
Table 7. Empirical equation of the number of points of sale $(P O S)$ in China, supporting non-cash payments via payment cards

\begin{tabular}{|c|c|c|c|c|}
\hline Variable & Coefficient & t-statistic & Prob. p & Significance \\
\hline const & -3037.44 & -3.7290 & 0.0007 & $* * *$ \\
\hline CARDPPL_1 & -47.7451 & -3.0276 & 0.0047 & $* * *$ \\
\hline CARDPPL_4 & 81.7423 & 4.2220 & $<0.0001$ & 10318.68 \\
\hline POS_1 & 0.684204 & 10.1767 & 668.2995 \\
\hline Mean dependent var. & 13426.08 & S.D. dependent var. & 0.995805 \\
\hline Sum squared resid. & 15185222 & S.E. of regression & $4.34 \mathrm{e}-41$ \\
\hline R-squared & 0.996145 & Adjusted R-squared & 605.9727 \\
\hline F(3, 34) & 2928.931 & Prob(F-statistic) & 608.3033 \\
\hline Log likelihood & -298.9864 & Akaike info criterion & 0.856729 \\
\hline Schwarz criterion & 612.5231 & Hannan-Quinn criterion & Durbin h-statistic & \\
\hline Autocorrel. coeff. (rho1) & 0.126482 & . & \\
\hline
\end{tabular}

Source: Own calculations using the GRETL package

Another variable characterizing the payment card market infrastructure in China is the number of the points of sale (POS) that support non-cash payments. The empirical equation of the number of the points of sale (POS) that support non-cash payments via payment cards in China is presented in Table 7. This equation describes the variability mechanism of the variable $P O S$ with high accuracy, since the $\mathrm{R}^{2}$ coefficient clearly exceeds 0.99 . This allows estimation of exact forecasts of the described variable $\left(P O S_{\mathrm{Tp}}\right)$.

The variability mechanism of the number of the points of sale is significantly similar to the variability mechanism of the number of ATMs. A positive first order autoregression, negative impact of the number of payment cards per capita in China delayed by 1 quarter (CARDPPL_1), and positive impact of the delayed-by-four-quarters number of cards (CARDPPL_4) occurs here. Forecasts of the number of the points of sale $\left(P O S_{\text {Tp }}\right)$, estimated using the empirical equation presented in Table 7, are presented in Table 8 and Figure 4.

The forecasts of the number of the points of sale servicing non-cash transactions via payment cards in China $\left(P O S_{\mathrm{Tp}}\right)$ for subsequent quarters of 2018-2020 are characterized by sufficient precision. Their relative prediction errors range from $2.08 \%$ in the third quarter of 2018 to $2.48 \%$ in the first quarter of 2019 . A further increase in the number of the points of sale can be expected, which may reach over 32 million in the third quarter of 2018. In subsequent quarters of 2019 and in two quarters of 2020, a systematic increase in the number of the points of sale, to the level of 42.8 million POS, will occur in the second quarter of $2020^{5}$.

The last feature characterising the payment card market infrastructure in China is the number of merchants (MERCHANT). Table 9 presents an empirical equation describing this variable. The high description accuracy, resulting from the $\mathrm{R}^{2}$ coefficient exceeding 0.99 , allows an expectation of accurate forecasts of the number of merchants $\left(M E R C H A N T_{\mathrm{Tp}}\right)$. The stimulus for the number of merchants is the delayed-by-four-quarters number of payment cards per capita on the Chinese market (CARDPPL_4). Moreover, first- and third-order autoregressions occur, whereby the first- and the third-order autoregressions are positive (MERCHANT_l, MERCHANT_3).
5 Chinese payment card users currently have - in a statistical sense - much easier access to cashless payments in the POSs than, for example, Polish users. At the end of 2018, there were 11380 points of sale per 1 million payment cards in Poland, whereas in China there were 46622 respectively [source: Wiśniewski J.W, Sokołowska E., Wu Jinghua (2018), The mechanisms of changes in the infrastructure of the payment card market. A comparative analysis of Poland and China, Conference "Rynek Kapitałowy. Skuteczne inwestowanie 2018", Międzyzdroje, 17-19.09.2018 (a paper presented at the conference)]. 
Table 8. Forecasts of the number of the points of sale servicing non-cash payments via payment cards in China (POSTp) for subsequent quarters of 2018-2020

\begin{tabular}{|c|c|c|c|c|}
\hline $\begin{array}{c}\text { Forecasted period } \\
(\mathrm{T})\end{array}$ & Forecast $\left(P O_{\mathrm{T}_{\mathrm{p}}}\right)$ & $\begin{array}{c}\text { Average prediction } \\
\text { error }\left(\mathrm{V}_{\mathrm{T}}\right)\end{array}$ & Relative prediction error $\mathbf{V}_{\mathbf{T}}^{*}(\% \%)$ & $\begin{array}{c}\text { Forecast range at a } \\
\text { confidence level of } 95 \%\end{array}$ \\
\hline $2018: 3$ & 32087.3 & 668.3 & 2.08 & $(30729.1 ; 33445.4)$ \\
\hline $2018: 4$ & 33047.5 & 809.8 & 2.45 & $(31401.9 ; 34693.1)$ \\
\hline $2019: 1$ & 34997.0 & 868.1 & 2.48 & $(33232.8 ; 36761.2)$ \\
\hline $2019: 2$ & 36713.0 & 894.1 & 2.44 & $(34895.9 ; 38530.0)$ \\
\hline $2019: 3$ & 38382.2 & 906.0 & 2.36 & $(36541.0 ; 40223.4)$ \\
\hline $2019: 4$ & 39975.9 & 911.5 & 2.28 & $(38123.4 ; 41828.3)$ \\
\hline $2020: 1$ & 41661.7 & 914.1 & 2.19 & $(39804.0 ; 43519.4)$ \\
\hline $2020: 2$ & 42785.1 & 915.3 & 2.14 & $(40924.9 ; 44645.2)$ \\
\hline
\end{tabular}

Source: Own calculations using the GRETL package

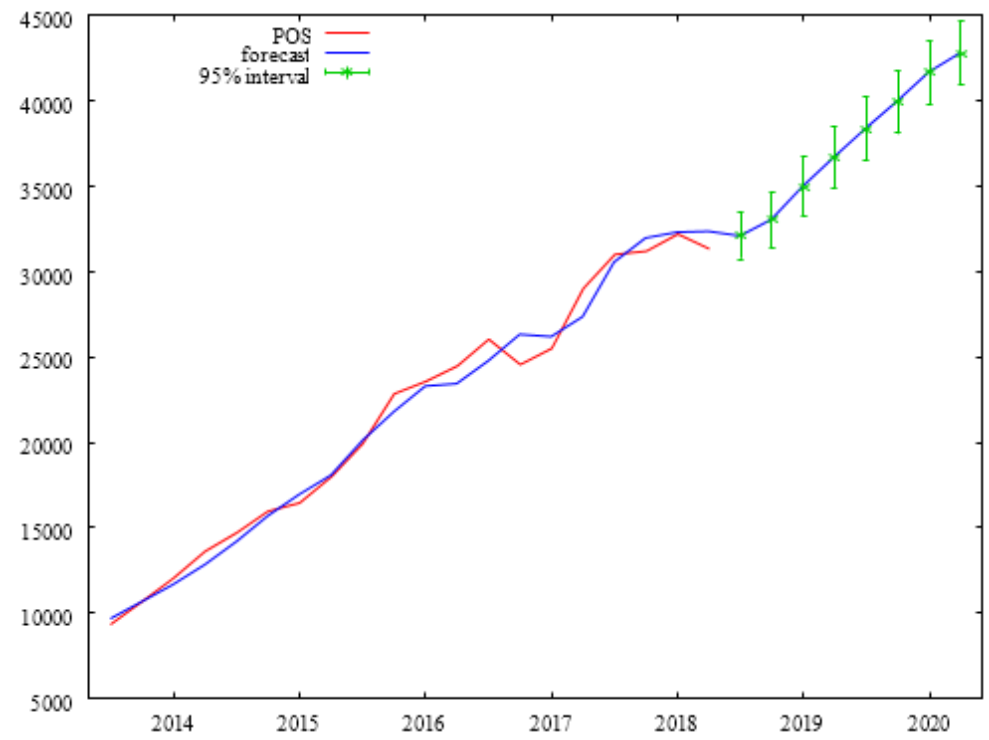

Source: Own calculations using the GRETL package

Figure 4. Forecasts of the number of the points of sale servicing non-cash payments via payment cards in China $\left(P O S_{\mathrm{Tp}}\right)$ for subsequent quarters of 2018-2020

Table 9. Empirical equation of the number of merchants (MERCHANT) on the payment card market in China

\begin{tabular}{|c|c|c|c|c|}
\hline Variable & Coefficient & t-statistic & Prob. p & Significance \\
\hline const & -4.87142 & -4.1557 & 0.0002 & $* * *$ \\
\hline CARDPPL_4 & 0.0554009 & 3.6852 & 0.0008 & $* * *$ \\
\hline time & -0.247172 & -2.5002 & 0.0176 & $* *$ \\
\hline MERCHANT_1 & 0.34531 & 2.4270 & 0.0208 & $* .0098$ \\
\hline MERCHANT_3 & 0.327199 & 2.7422 & 8.654189 \\
\hline Mean dependent var. & 10.32350 & S.D. dependent var. & 0.516687 \\
\hline Sum squared resid. & 8.809855 & S.E. of regression & 0.996435 \\
\hline R-squared & 0.996821 & Adjusted R-squared & $1.07 \mathrm{e}-40$ \\
\hline F(4, 33) & 2586.764 & Prob(F-statistic) & 62.29415 \\
\hline Log likelihood & -26.14708 & Akaike info criterion & 65.20735 \\
\hline Schwarz criterion & 70.48208 & Hannan-Quinn criterion & 2.588808 \\
\hline Autocorrel. coeff. (rho1) & 0.201737 & Durbin h-statistic & \\
\hline
\end{tabular}

Source: Own calculations using the GRETL package 
Table 10. Forecasts of the number of merchants (MERCHANT $\left.T_{\mathrm{p}}\right)$ on the payment card market in China for subsequent quarters of 2018-2020

\begin{tabular}{|c|c|c|c|c|}
\hline $\begin{array}{c}\text { Forecasted period } \\
(\mathrm{T})\end{array}$ & $\begin{array}{c}\text { Forecast } \\
\left(\text { MERCHANT } T_{\mathrm{p}}\right)\end{array}$ & $\begin{array}{c}\text { Average prediction } \\
\text { error }\left(\mathrm{V}_{\mathrm{T}}\right)\end{array}$ & Relative prediction error $\mathbf{V}_{\mathbf{T}}^{*} \%$ \%) & $\begin{array}{c}\text { Forecast range at a } \\
\text { confidence level of 95\% }\end{array}$ \\
\hline $2018: 3$ & 28.0330 & 0.516687 & 1.84 & $(26.9818 ; 29.0842)$ \\
$2018: 4$ & 29.3354 & 0.546624 & 1.86 & $(28.2232 ; 30.4475)$ \\
$2019: 1$ & 30.6205 & 0.550085 & 1.80 & $(29.5013 ; 31.7396)$ \\
$2019: 2$ & 32.1469 & 0.582083 & 1.81 & $(30.9626 ; 33.3311)$ \\
$2019: 3$ & 33.4623 & 0.595165 & 1.78 & $(32.2514 ; 34.6732)$ \\
$2019: 4$ & 34.7460 & 0.598492 & 1.72 & $(33.5284 ; 35.9636)$ \\
$2020: 1$ & 36.2312 & 0.604363 & 1.67 & $(35.0016 ; 37.4608)$ \\
$2020: 2$ & 37.3961 & 0.608360 & 1.63 & $(36.1584 ; 38.6338)$ \\
\hline
\end{tabular}

Source: Own calculations using the GRETL package

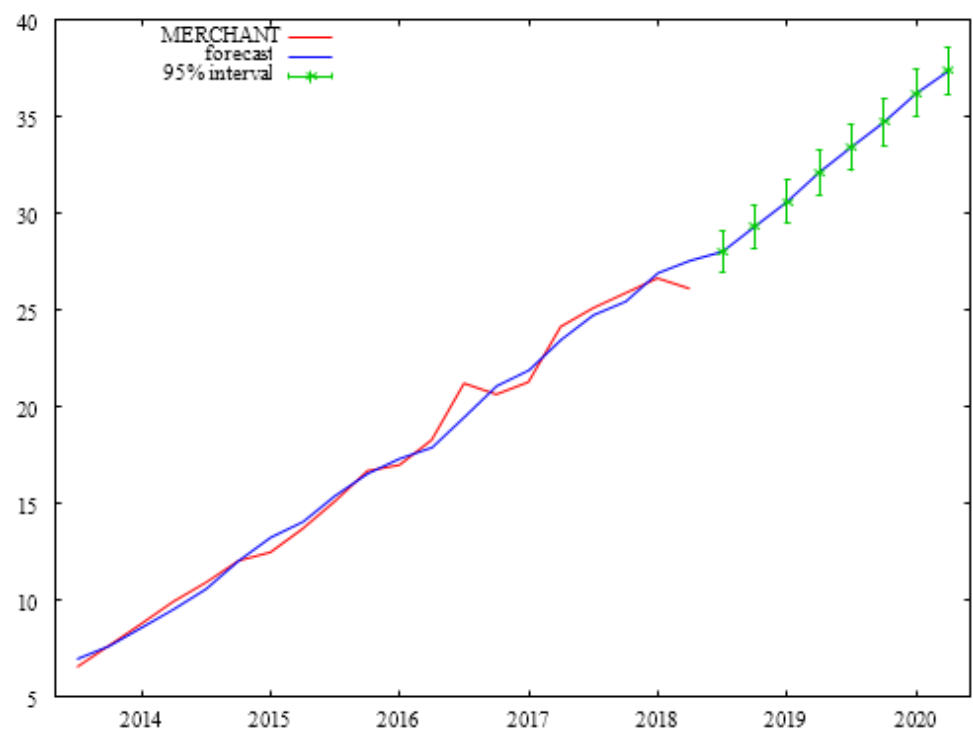

Source: Own calculations using the GRETL package

Figure 5. Forecasts of the number of merchants $\left(M E R C H A N T_{T_{\mathrm{p}}}\right)$ on the payment card market in China for the following quarters of 2018-2020

Table 10 and Figure 5 present quarterly forecasts of the number of payment card merchants in China $\left(M E R C H A N T_{\mathrm{Tp}}\right)$ for the years 2018-2019. Similarly, to the number of ATMs $\left(A T M_{\mathrm{Tp}}\right)$ and the number of the points of sale servicing non-cash payments $\left(P O S_{\mathrm{Tp}}\right)$ - a further increase in the number of merchants can be expected up until the second quarter of 2020. This number may increase from over 28 million in the third quarter of 2018 to around 37.4 million in the second quarter of 2020. The forecasts of the variable $\left(M E R C H A N T_{\mathrm{Tp}}\right)$ are sufficiently accurate, since their relative prediction errors range from $1.63 \%$ in the second quarter of 2020 to $1.86 \%$ in the fourth quarter of 2018 .

Assessment of the intensity of cashless payments via payment cards in China was carried out using the variable VALTRCD expressing the quarterly value of these payments per 1 payment card. The empirical equation describing this variable contains, among its explanatory variables, a measure of the saturation of payment cards with merchants $(M E R C D)$. It is therefore necessary to obtain an empirical equation describing this variable. Table 11 presents the empirical equation describing the variable $M E R C D$. The structure of this equation is complicated. The simultaneous and the delayed-by-one-quarter urban population's average pay (APAY, APAY_l) occur in it as brakes on the number of merchants per 1 million payment cards. The average quarterly pay, delayed by 2 quarters (APAY_2), has turned out to be a stimulator of the variable $M E R C D$. The delayed-by-four-quarters total number of payment cards on the Chinese market $\left(C A R D \_4\right)$ has increased the value of the variable $M E R C D$. A negative seasonal deviation in the third quarter of the year occurred as well. Finally, first-, third- and fourth-order autoregressions have occurred. The first- and the third-order autoregressions are positive (MERCD_1, MERCD_3). In contrast, the fourth-order autoregression is negative (MERCD_4). The equation describes the variation mechanism of the variable $M E R C D$ with high accuracy. The value of the $\mathrm{R}^{2}$ coefficient clearly exceeds 0.99 . This suggests a 
possibility of obtaining precise forecasts of the number of merchants per 1 million payment cards in China $\left(M E R C D_{\mathrm{Tp}}\right)$.

The last characteristic of the payment card market infrastructure in China is the number of merchants per 1 million payment cards $(M E R C D)$. The empirical equation describing this variable is presented in Table 11. The high description accuracy, resulting from the value of the $\mathrm{R}^{2}$ coefficient exceeding 0.99 , allows expectation of accurate forecasts of the number of merchants per 1 million cards $\left(M E R C D_{\mathrm{Tp}}\right)$. The variable $M E R C D$ constitutes the only case where an infrastructure component is dependent on the average quarterly pay. The current $(A P A Y)$ and the delayed-by-one-quarter (APAY_l) urban population's average pay are brakes on the development of the number of merchants. The delayed-by-two-quarters (APAY_2) average pay of the urban population is a stimulus for the development of the number of merchants $(M E R C D)$. The number of payment cards per 100 inhabitants on the Chinese market, delayed by four quarters (CARDPPL_4), is also a stimulant of the number of merchants. Moreover, first-, third- and fourth-order autoregressions occur, with the first- and the third-order autoregressions being positive (MERCD_1, MERCD_3), while the fourth-order autoregression (MERCD_4) is negative. Additionally, a negative seasonal deviation of the variable $M E R C D$ occurs in the third quarter of the year.

Forecasts of the number of merchants per 1 million payment cards in China $\left(M E R C D_{\mathrm{Tp}}\right)$ are given in Table 12 and Figure 6. These forecasts are characterized accuracy similar to that of previous variables, the average relative forecast error of which ranges from $2.04 \%$ in the third quarter of 2018 to $2.71 \%$ in the second quarter of 2019 . These forecasts can be considered acceptable. The forecasts indicate an increase in the number of merchants per 1 million payment cards up to the fourth quarter of 2020, when more than 51 thousand of merchants per 1 million payment cards can be expected. The number of merchants per 1 million cards increases faster along with the dynamic increase in the number of payment cards on the Chinese market. This is to facilitate cashless payments for the payment card holders.

Table 11. Empirical equation of the number of merchants $(M E R C D)$ on the Chinese payment card market per 1 million payment cards

\begin{tabular}{|c|c|c|c|c|}
\hline Variable & Coefficient & t-statistic & Prob. $p$ & Significance \\
\hline const & 0.997297 & 0.7222 & 0.4760 & \\
\hline APAY & -0.00279936 & -4.4107 & 0.0001 & $* * *$ \\
\hline APAY_1 & -0.00264806 & -2.9883 & 0.0057 & $* * *$ \\
\hline APAY_2 & 0.00351777 & 2.4897 & 0.0188 & $* *$ \\
\hline CARDPPL_4 & 0.0674886 & 3.1484 & 0.0038 & $* * *$ \\
\hline $\mathrm{dq} 3$ & -3.67351 & -2.5052 & 0.0181 & $* *$ \\
\hline MERCD_1 & 0.609537 & 3.3860 & 0.0021 & $* * *$ \\
\hline MERCD_3 & 0.559951 & 3.4458 & 0.0018 & $* * *$ \\
\hline MERCD_4 & -0.669766 & -3.8812 & 0.0006 & $* * *$ \\
\hline Mean dependent var. & 20.26542 & \multicolumn{2}{|c|}{ S.D. dependent var. } & 11.28388 \\
\hline Sum squared resid. & 19.01502 & \multicolumn{2}{|c|}{ S.E. of regression } & 0.809747 \\
\hline R-squared & 0.995964 & \multicolumn{2}{|c|}{ Adjusted R-squared } & 0.994850 \\
\hline $\mathrm{F}(8,29)$ & 894.4864 & \multicolumn{2}{|c|}{ Prob(F-statistic) } & $1.43 \mathrm{e}-32$ \\
\hline Log likelihood & -40.76488 & \multicolumn{2}{|c|}{ Akaike info criterion } & 99.52977 \\
\hline Schwarz criterion & 114.2680 & \multicolumn{2}{|c|}{ Hannan-Quinn criterion } & 104.7735 \\
\hline Autocorrel. coeff. (rho1) & 0.185838 & \multicolumn{2}{|c|}{ Durbin h-statistic } & 1.547311 \\
\hline
\end{tabular}

Source: Own calculations using the GRETL package

Table 12. Quarterly forecasts of the number of merchants per 1 million payment cards in China $\left(M E R C D_{\mathrm{Tp}}\right)$ for the years 2018 - 2020

\begin{tabular}{|c|c|c|c|c|}
\hline $\begin{array}{c}\text { Forecasted period } \\
(\mathrm{T})\end{array}$ & $\begin{array}{c}\text { Forecast } \\
\left(M E R C D_{\mathrm{Tp}}\right)\end{array}$ & $\begin{array}{c}\text { Average prediction error } \\
\left(\mathrm{V}_{\mathrm{T}}\right)\end{array}$ & Relative prediction error $\mathbf{V}_{\mathbf{T}}^{*}(\% \%)$ & $\begin{array}{c}\text { Forecast range at a } \\
\text { confidence level of } 95 \%\end{array}$ \\
\hline $2018: 3$ & 39.6345 & 0.809747 & 2.04 & $(37.9784 ; 41.2906)$ \\
\hline $2018: 4$ & 40.3953 & 0.948316 & 2.35 & $(38.4558 ; 42.3348)$ \\
\hline $2019: 1$ & 39.5609 & 0.994894 & 2.51 & $(37.5262 ; 41.5957)$ \\
\hline $2019: 2$ & 43.5378 & 1.18124 & 2.71 & $(41.1219 ; 45.9537)$ \\
\hline $2019: 3$ & 47.5027 & 1.18754 & 2.50 & $(45.0739 ; 49.9315)$ \\
\hline $2019: 4$ & 48.4608 & 1.19077 & 2.46 & $(46.0254 ; 50.8962)$ \\
\hline $2020: 1$ & 50.1218 & 1.19510 & 2.38 & $(47.6775 ; 52.5660)$ \\
\hline $2020: 2$ & 51.6181 & 1.23124 & 2.39 & $(49.0999 ; 54.1363)$ \\
\hline
\end{tabular}

Source: Own calculations using the GRETL package 


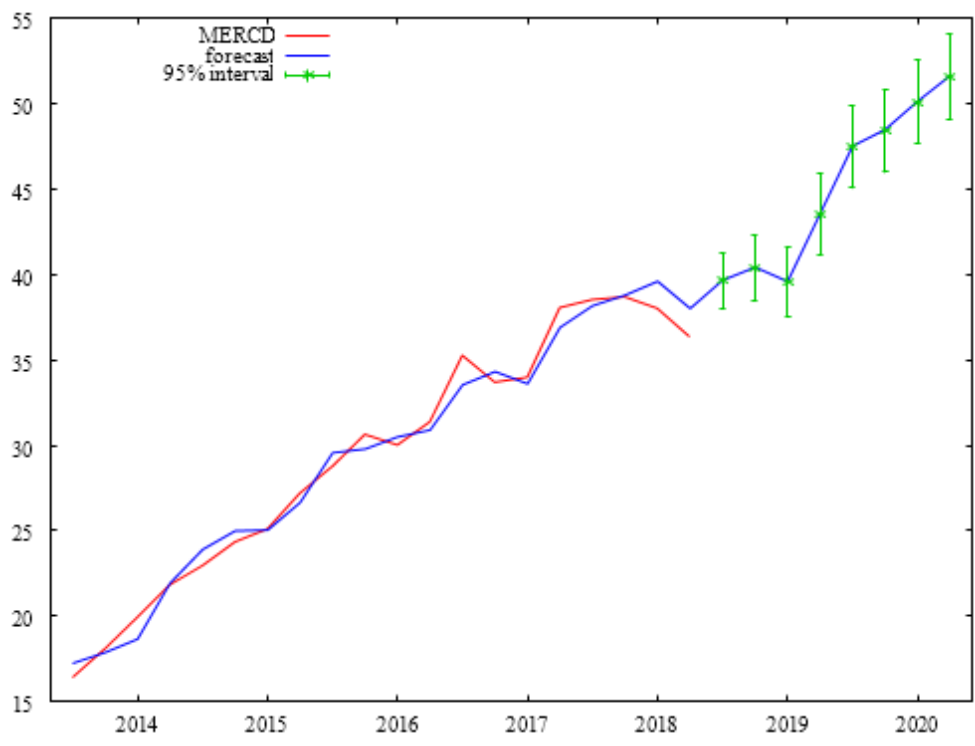

Source: Own calculations using the GRETL package

Figure 6. Quarterly forecasts of the number of merchants per 1 million payment cards in China $\left(M E R C D_{\mathrm{Tp}_{\mathrm{p}}}\right)$ for the years $2018-2020$

Table 13. Empirical equation of quarterly values of non-cash payments via payment cards in China per one card (VALTRCD)

\begin{tabular}{|c|c|c|c|c|}
\hline Variable & Coefficient & Std. Error & Prob. $\mathrm{p}$ & Significance \\
\hline const & 315.568 & 76.9461 & 0.0003 & $* * *$ \\
\hline MERCD & -5.5586 & 2.30499 & 0.0227 & $* *$ \\
\hline MERCD_1 & 5.6399 & 2.16094 & 0.0144 & $* *$ \\
\hline APAY_3 & -0.0820463 & 0.0279889 & 0.0067 & $* * *$ \\
\hline time & 8.44463 & 2.68149 & 0.0039 & $* * *$ \\
\hline $\mathrm{dq} 1$ & -73.1181 & 24.8038 & 0.0064 & $* * *$ \\
\hline $\mathrm{dq} 2$ & -63.3014 & 19.6915 & 0.0033 & $* * *$ \\
\hline $\mathrm{dq} 3$ & -58.7532 & 19.2626 & 0.0050 & $* * *$ \\
\hline VALTRCD_1 & 0.736008 & 0.0887095 & $<0.0001$ & $* * *$ \\
\hline VALTRCD_4 & -0.236343 & 0.083981 & 0.0088 & $* * *$ \\
\hline \multicolumn{2}{|c|}{ Mean dependent var. } & 4562 & S.D. dependent var. & 38.12205 \\
\hline \multicolumn{2}{|c|}{ Sum squared resid. } & 1.736 & S.E. of regression & 13.94086 \\
\hline \multicolumn{2}{|c|}{ R-squared } & 8799 & Adjusted R-squared & 0.866271 \\
\hline \multicolumn{2}{|c|}{$\mathrm{F}(9,28)$} & 3091 & Prob(F-statistic) & $1.23 \mathrm{e}-11$ \\
\hline \multicolumn{2}{|c|}{ Log likelihood } & 8.2407 & Akaike info criterion & 316.4815 \\
\hline \multicolumn{2}{|c|}{ Schwarz criterion } & .8573 & Hannan-Quinn criterion & 322.3079 \\
\hline \multicolumn{2}{|c|}{ Autocorrel. coeff. (rho1) } & 13938 & Durbin h-statistic & 1.575190 \\
\hline
\end{tabular}

Source: Own calculations using the GRETL package

Table 13 presents an empirical equation of the value of quarterly payment-card payments per 1 card (expressed in RMB). The description accuracy of the variable $V A L T R C D$ can be considered moderate. The value of $\mathrm{R}^{2}=$ 0.899 suggests that the $V A L T R C D_{\mathrm{Tp}}$ forecasts can be expected to be less precise, compared to those presented earlier on. The number of merchants per 1 million payment cards significantly affected the variable
VALTRCD, both simultaneously $(M E R C D)$ and with a delay of 1 quarter (MERCD_1). The simultaneous increase in the value of the variable $M E R C D$ reduces the value of the variable $\operatorname{VALTRCD}$, while its delay by 1 quarter is a stimulant of the dependent variable under consideration. Statistically significant impact on the variable VALTRCD is exerted by the urban population's average quarterly pay delayed by three quarters ( $\left.A P A Y \_3\right)$, 
which is an inhibiting factor. The first-order (positive) and the fourth-order (negative) autoregressions play a significant role. What is more, the variable VALTRCD is seasonal in each quarter. Seasonal fluctuations are statistically significant in each quarter, adding up to zero. In subsequent quarters, they amount to the following amounts:

$-38.1 \mathrm{RMB} / 11$ card in the first quarter,

$+5.0 \mathrm{RMB} / 11$ card in the second quarter,

$-0.4 \mathrm{RMB} / 11$ card in the third quarter,

$+33.5 \mathrm{RMB} / 11$ card in the fourth quarter.

Table 14 and Figure 7 present forecasts of the payment values (expressed in RMB) per 1 payment card $\left(\right.$ VALTRCD $\left._{\mathrm{Tp}}\right)$ for subsequent quarters of 2018-2019. These forecasts are characterized by fairly high relative prediction errors. They range from $4.27 \%$ in the third quarter of 2018 to $6.69 \%$ in the fourth quarter of 2019 . It can be expected that in the period from the third quarter of 2018 to the second quarter of 2020, the value of non-cash transactions per 1 payment card will range from about RMB 295 to over 339 / 1 card. Non-cash payments in China will thus remain at a relatively low level, in relation to the average pay and against the background of the intensity of such payments in the European Union.

Table 14. Forecasts of the payment value (expressed in RMB) per 1 payment card quarterly $\left(\right.$ VALTRCD ${ }_{\mathrm{Tp}}$ ) for the years 2018 - 2020

\begin{tabular}{|c|c|c|c|c|}
\hline $\begin{array}{c}\text { Forecasted } \\
\text { period (T) }\end{array}$ & $\begin{array}{c}\text { Forecast } \\
\left(\text { VALTRCD }_{\mathrm{Tp}}\right)\end{array}$ & $\begin{array}{c}\text { Average prediction } \\
\text { error }\left(\mathrm{V}_{\mathrm{T}}\right)\end{array}$ & Relative prediction error $\mathbf{V}_{\mathbf{T}}^{*}(\%)$ ) & $\begin{array}{c}\text { Forecast range at a confidence } \\
\text { level of } 95 \%\end{array}$ \\
\hline $2018: 3$ & 326.573 & 13.9409 & 4.27 & $(298.016 ; 355.130)$ \\
\hline $2018: 4$ & 315.161 & 17.3097 & 5.49 & $(279.704 ; 350.618)$ \\
\hline $2019: 1$ & 339.295 & 18.8854 & 5.57 & $(278.063 ; 358.714)$ \\
\hline $2019: 2$ & 318.388 & 19.6863 & 6.18 & $(267.361 ; 348.078)$ \\
\hline $2019: 3$ & 307.719 & 19.7024 & 6.40 & $(255.095 ; 336.163)$ \\
\hline $2019: 4$ & 295.629 & 19.7881 & 6.69 & $(264.724 ; 346.806)$ \\
\hline $2020: 1$ & 305.765 & 20.0354 & 6.55 & $(274.828 ; 358.241)$ \\
\hline $2020: 2$ & 316.534 & 20.3604 & 6.43 & \\
\hline
\end{tabular}

Source: Own calculations using the GRETL package

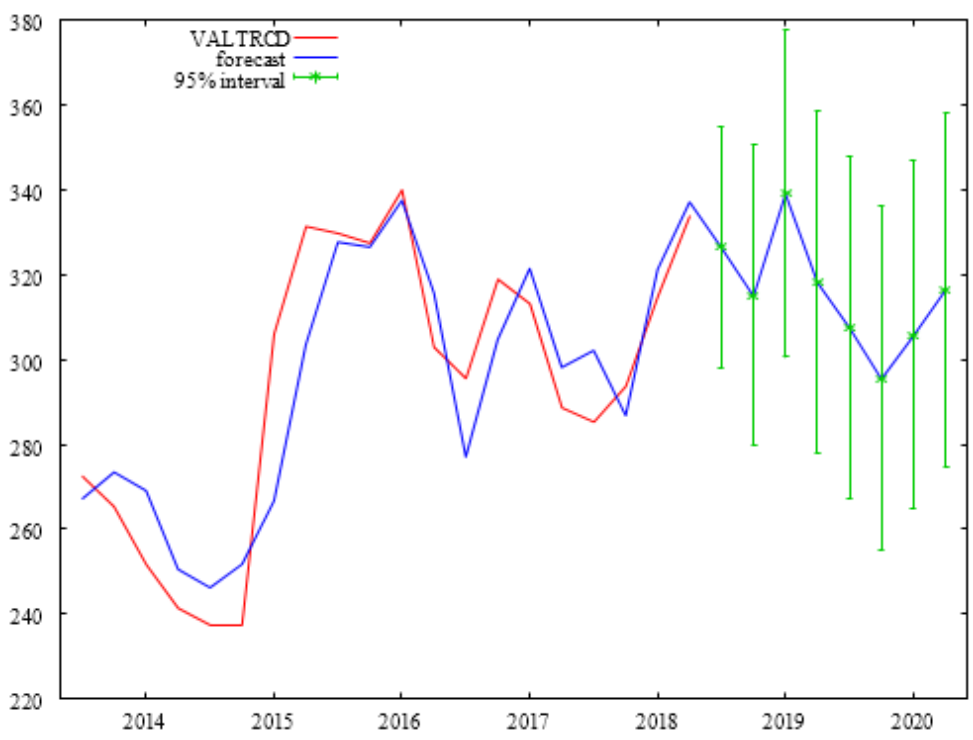

Source: Own calculations using the GRETL package

Figure 7. Forecasts of the payment value (expressed in RMB) per 1 payment card quarterly $\left(\right.$ VALTRCD $D_{\mathrm{Tp}}$ ) for the years $2018-2020$ 


\section{Conclusions}

The rising pay in China stimulates the dynamic development of the payment card market. The number of these cards and their use for cashless transactions have been increasing in particular. Cashless card payments in China are currently at a relatively low level. To increase the intensity of such payments, new institutional solutions are required, especially of an economic nature, encouraging the payment card holders to carry out non-cash transactions. In this area of life, citizen conservatism is seen, causing aversion to financial novelties. Non-cash payments result in increased control over people, which the Chinese probably defend against.

The lack of institutional changes on the Chinese payment card market may cause stagnation in the value of cashless card payments. In contrast, further expansion of the infrastructure supporting payment cards can be expected in the next two years. The total number of cards and the number of cards per 1000 inhabitants will also increase systematically.

\section{REFERENCES}

[1] Amromin G., Chakravorti S. (2007): Debit Card and Cash Usage: A Cross-Country Analysis, "Social Science Research", Network Working Paper Series.

[2] Evans D. S., Webster K., Colgan G. K., Murray S. R. (2013): Payments Innovation and the Use of Cash, Social Science Research Network Working Paper Series (5 June 2013).

[3] Goldberger A. S. (1972): Teoria ekonometrii, PWE Warsaw.

[4] Hancock, D., Humphrey, D. B., \& Wilcox, J. (1999): Cost reductions in electronic payments: the roles of consolidation, economies of scale, and technical change. "Journal of Banking \& Finance", 23, 391-421. CrossRef.

[5] Hauswald, R., \& Marquez, R. (2003): Information technology and financial services. Competition Review of Financial Studies", 16(3), 921-948.CrossRef.

[6] Humphrey, D. B., Pulley, L. B., \& Vesala, J. M. (1996): Cash, paper, and electronic payments: a cross-country analysis. "Journal of Money", Credit and Banking, 914-939.

[7] http://www.nbp.pl/home.aspx?f=/systemplatniczy/karty_pla tnicze.html.

[8] Rysman M. (2007): An empirical analysis of payment card usage, "Journal of Industrial Economics", Vol. 55, No. 1, pp. 1-36, doi:10.1111/j.1467-6451.2007. 00301.x

[9] Sokołowska E. (2015a): Innovations in the payment card market: The case of Poland. Electronic Commerce Research and Applications, 14(5), pp. 292-304.

[10] Sokołowska E. (2015b): The principles of alternative investments management: a study of the global market, Springer International Publishing Switzerland, Cham.

[11] Sokołowska E., Wiśniewski J.W. (2015): Forecasts of payment card payments against the changes in the infrastructure of the payment system in Poland, 10th International Scientific Conference, Financial Management of Firms and Financial Institutions, 7th - 8th September 2015, Ostrava, Czech Republic VŠB - Technical University of Ostrava Faculty of Economics, Department of Finance, part IV, pp. $1174-1182$.

[12] Sokołowska E., Wiśniewski J.W. (2015): Forecasts of payment card payments against the changes in the infrastructure of the payment system in Poland, 10th International Scientific Conference, 7th-8th September 2015, Ostrava, Czech Republic: proceedings. Pt. 4 / ed. Miroslav Čulík, pp.1174-1182.

[13] Tufano, P. (2003): Financial innovation. Handbook of the Economics of Finance, 1, 307-335.

[14] Wiśniewski J.W., Zieliński Z.: Elementy ekonometrii (Elements of econometrics), UMK, Toruń, 2004, Revised 5th Edition.

[15] Wiśniewski J. W. (2016): Microeconometrics in Business Management, John Wiley \& Sons, Chichester.

[16] Wiśniewski J. W., Sokołowska E., Wu Jinghua (2017): The Dynamics of the Payment Card Market. A Comparative Analysis of Poland and China, [in]: Szkutnik W., Sączewska-Piotrowska A., Hadaś-Dyduch M., Acedański J. (eds.), 8th International Scientific Conference "Analysis of International Relations 2017. Methods and Models of Regional Development". Conference Proceedings, Publishing House of the University of Economics in Katowice, pp. $132-141$.

[17] Wiśniewski J. W. (2018): Substitution of payments on the payment cards market in Poland, X International Scientific Conference Analysis of International Relations 2018. Methods and Models of Regional Development, Summer Edition, Katowice, 19-20 June 2018.

[18] Wiśniewski J.W, Sokołowska E., Wu Jinghua (2018), The Mechanisms of Changes in the Infrastructure of the Payment Card Market-A Comparative Analysis of Poland and China, In book: Effective Investments on Capital Markets, Springer Nature Switzerland AG, pp. 457-471. 